the regulation of the legal support for the economic activities of religious organizations, it is necessary to supplement the national legislation (the Commercial Code of Ukraine, the Law of Ukraine «On the Freedom of Conscience and Religious Organizations», etc.) with certain provisions as regards such activities.

\title{
References:
}

1. Suvorov, N. S. (2000). Ob yuridicheskikh litsakh po rimskomu pravu [About legal entities under Roman law]. Moscow: Statut. (in Russian)

\section{ON THE REALIZATION OF THE PERSONAL NON-PROPERTY RIGHT TO HEALTH INFORMATION}

\section{Inna Horislavska ${ }^{1}$ Maryna Ruda ${ }^{2}$}

DOI: https://doi.org/10.30525/978-9934-588-39-6-42

The World Health Organization notes the main issue that needs to be addressed - patient safety as prevention, avoidance, minimization of adverse effects of treatment. Normatively established obligation of the provider of the medical service (i.e. on its own initiative, which does not require prior consent or coordination with the patient) to provide information to the consumer.

In terms of the content, and to the extent that it objectively enables a conscious decision to be made, regardless of the medical specificity of the information that characterizes the obligations to be undertaken, and sets out their limits, such information must demonstrate that the violation of these limits is wrongful for the information which, in an accessible form, discloses the danger that the medical effect, its attendant or further consequences are concealed [1].

The corresponding position is justified by Article 285 of the Civil Code of Ukraine [2], item 4 of Article 4 of the Law of Ukraine «On Protection of Consumer Rights» [3] - Consumers, when concluding, amending, executing and terminating contracts, are entitled to necessary, accessible, reliable and timely information in the state language about the products, their quantity, quality, assortment, its executor, as well as Article 39 of the Fundamental Principles of Healthcare Legislation of Ukraine (hereinafter the «Fundamental

\footnotetext{
${ }^{1}$ National University of Life and Environmental Sciences of Ukraine, Ukraine

${ }^{2}$ National University of Life and Environmental Sciences of Ukraine, Ukraine
} 
Principles») [4]. The other «party» with regard to provision of information by the executor of the agreement on provision of medical services is the category medical secrecy provided for by Article 40 Fundamental Principles; the issue of its disclosure through the implementation of the procedure for filling in the inoperability sheet and the implementation of the right patient (his/her representative) or heir to such information.

The Inoperability Leaf is an element of primary medical documentation and contains, inter alia, information (diagnosis - cipher of diagnosis according to the International Statistical Classification of Diseases and Related Health Problems of the 10th revision) that constitutes medical secrecy. The relevant provisions are contained in the Instructions on how to fill in the inoperability sheet (item 3.2.) [5]; The procedure of organization of maintenance of the electronic register of inoperability sheets and provision of information from it (part 8, item 10; part 6, item 13) [6].

The Ministry of Economy, Trade and Agriculture approved two national classifiers of the Ministry of Health of Ukraine, which will be used by medical workers of all health care institutions for encoding of diagnoses and medical interventions in the electronic health care system (National Classifier 025: 2019 «Classifier of Diseases and Related Health Problems» and National Classifier 026: 2019 «Classifier of Medical Interventions») [7]. It will be used in the formation and implementation of the system of financing health care institutions in Ukraine, which provide specialized outpatient and hospital medical care.

The issue of compliance with the regulatory requirements of confidentiality with regard to such information is still unresolved, the more so considering the formation of a web-oriented service to ensure information interaction of the electronic health care system with the Electronic Register of Inoperability Leafs [8].

The exercise of the right of the patient (his/her representative) or heir to information that constitutes medical secrecy and information about the state of health, including the right to review relevant medical documents that relate to the state of health, is a problematic issue in the contract on the provision of medical services. If we talk about the implementation and enforcement of personal non-property rights, which ensure the natural existence of an individual (Articles 282-286 of the Civil Code of Ukraine), the legal mechanisms of legislation on consumer protection, legislation on information provide an opportunity for the appropriate implementation.

However, obtaining information from medical records to determine the cause of death of a person by its heirs is a complex process. For example, the decision in case № 201/2923/19 of the Oktyabrskiy District Court of Dnipro satisfied the claim against the Communal enterprise «Dnipropetrovsk 
Regional Clinical Hospital named after I. I. Mechnikov» about demanding the appropriate medical documentation from the patient's chart [9]. The health care institution refused to provide full information, disassociating part of it, and justified it as a medical secret and one that concerned the patient (daughter of the plaintiff) personally.

The law grants the right in the event of an individual's death to members of her family or other individuals who are authorized by them, to be present during the study of the causes of her death and to familiarize themselves with the findings regarding the causes of her death, as well as the right to appeal these findings to the court (part 4 of article 285 of the Civil Code of Ukraine, art. 39 of the Fundamental Principles). However, we are talking only about persons who belong to the first line of heirs (Art. 1261 of the Civil Code of Ukraine), and if the inheritance is called on representatives of other queues, then respectively they are deprived of the right to obtain relevant information. They will not be able to «use» the right to terminate the contract for the provision of medical services and return the money paid for the goods (Article 8 of the Law of Ukraine «On Protection of Consumer Rights»), respectively, because it is possible to prove "poor quality medical services» only on the basis of the conclusion of an expert who needs medical documentation.

Obviously, the introduction of effective legal mechanisms should help to improve the level of protection of rights, freedoms and interests of citizens. The issue of obtaining information on the state of health of a person by its heirs is a promising one and one that requires amendments to the legislation.

\section{References:}

1. Maidanyk, R. (2010). Dogovir pro nadannya medychnyx poslug [Contract for the provision of health services]. Medychne pravo [Medical law], vol. 1, no. 5, pp. 52-66. URL: http://medicallaw.org.ua/uploads/media/Maydanyk.pdf (accessed 10.03.2020).

2. The Law of Ukraine dated January 16, 2003 № 435-IV «The Civil Code of Ukraine». URL: http://zakon3.rada.gov.ua/laws/show/435-15/page6 (accessed: 10.03.2020).

3. The Law of Ukraine dated May 12, 1991 № 1023-XII «On consumer protection». URL: https://zakon.rada.gov.ua/laws/show/1023-12 (accessed: 10.03.2020).

4. The Law of Ukraine dated November 19, 1992 № 2801-XII «Basics of Ukrainian health care legislation». URL: https://zakon.rada.gov.ua/laws/show/280112/ed19970313 (accessed 11.03.2020).

5. Order of the Ministry of Health of Ukraine, Ministry of Labour and Social Policy of Ukraine, Temporary Disability Social Insurance Fund, Fund for Social Insurance against Industrial Accidents and Occupational Diseases of Ukraine of Ukraine dated November 03, 2004 № 2801-XII «Instruction on the procedure for completing the incapacity to work sheet». URL: https://zakon.rada.gov.ua/ laws/show/z1456-04 (accessed: 11.03.2020).

6. Ukrainian Cabinet of Ministers Resolution dated April 17, 2019 № 328 « Some issues regarding the organization of the electronic disability registry and the provision 
of information from it». URL: https://zakon.rada.gov.ua/laws/show/328-2019\%D0\%BF (accessed: 11.03.2020).

7. Order of the Ministry of Economic Development, Trade and Agriculture of Ukraine dated December 13, 2019 № 677 « Classifier of diseases and health problems 025: 2019». URL: https://moz.gov.ua/dokumenti_(accessed: 11.03. 2020).

8. Ukrainian Cabinet of Ministers Resolution dated March 03, 2020 № 159 «Peculiarities of maintaining an electronic register of incapacitation lists to ensure informational interaction of eHealth with the electronic register of incapacitation lists». URL: $\quad$ https://www.kmu.gov.ua/npas/pro-osoblivosti-vedennya-elektronno-a159 (accessed: 11.03.2020).

9. The decision of the Oktyabrsk district court of the city. Dnipro of February 14, 2020 № 201/2923/19. URL: http://www.reyestr.court.gov.ua/Review/87587340 (accessed: 11.03.2020).

\section{THE CURRENT STATE OF THE MEDICAL CRIME IN UKRAINE}

\section{Kateryna Plutytska ${ }^{1}$}

DOI: https://doi.org/10.30525/978-9934-588-39-6-43

One of the priority activities of the government is to ensure an adequate standard of living and health of the population, including by maintaining and / or implementing effective legal and social mechanisms. Health care authorities play a leading role in ensuring a decent level of public health and in providing quality health care. However, there are numerous problems in the activities of these bodies, which are becoming more and more relevant over time. First of all, they include, the inadequate quality of medical care providing, the improper treatment of the professional duties, the abuse of the rank, the illegal experimentation on a human being, the illegal trafficking of the counterfeit medicinal products, etc. Further, the euthanasia still is the moot point. At the same time, according to the Art. 115 «Murder» of the Criminal Code of Ukraine euthanasia is a crime and entails criminal liability.

Now, the Criminal Code of Ukraine provides criminal liability for a number of crimes committed in the medical sphere, the main object of which is the life and health of man, namely: art. 131 «Professional misconduct causing infection of a person with HIV or any other incurable contagious disease», art. 132 «Disclosure of information on medical examination for HIV or any other incurable contagious disease», art. 134 «Illegal abortion or sterilization», art. 138 «Illegal medical practice»; article 139 «Failure of a

\footnotetext{
${ }^{1}$ Zaporizhzhia National University, Ukraine
} 